\title{
PEMBUATAN VIRTUAL KAMPUS SISTEM KOMPUTER FAKULTAS TEKNIK UNIVERSITAS DIPONEGORO MENGGUNAKAN JARINGAN
}

\section{LOKAL BERBASIS VRML}

\author{
Hendra Taufiq Oktafianto ${ }^{11}$, Kodrat Iman Satoto ${ }^{2)}$, Kurniawan Teguh Martono ${ }^{2)}$ \\ Program Studi Sistem Komputer, Fakultas Teknik, Universitas Diponegoro \\ Jln. Prof. Sudharto, Tembalang, Semarang, Indonesia \\ Email: hendrataufiq@gmail.com
}

\begin{abstract}
Abstrak-Dalam bidang informasi banyak cara dalam menginformasikan data, baik secara tertulis, gambar, suara, gambar dan suara. Saat ini banyak dikembangkan teknologi dengan menggunakan metode visual yang interaktif, seperti dunia virtual yang membuat seolah-olah informasi tersebut di dapat sesuai dengan pengalaman memasuki daerah yang di lihat pada dunia virtual tersebut. Metode tersebut adalah pengembangan teknologi virtual reality yang dibuat dengan menggunakan 3DS Max sebagai software untuk menghasilkan gambar yang menarik. Pengaplikasian yang dikembangkan dengan media web dimana setiap pengguna lebih mudah dalam dalam menggunakan aplikasi tersebut.

Metode pengambangan yang dirancang adalah memadukan teknologi virtual reality dengan web. Dimana aplikasi tersebut terdapat didalam tampilan web yang didukun basis data untuk mempermudah aktor admin dalam mengolah data. Pada browser yang digunakan akan di pasang plug-in cortona3d agar dapat menampilkan file ekstensi tiga dimensi yang dapat di tampilkan browser.

Hasil dari pembuatan aplikasi ini adalah terancangnya sebuah aplikasi yang menggunakan teknologi virtual reality modeling language dengan studi kasus Kampus Sistem Komputer Fakultas Teknik Universitas Diponegoro menggunakan jaringan lokal berbasis VRML.
\end{abstract}

Kata Kunci : Aplikasi Virtual, Virtual Reality, 3DS Max, web, plug-in Cortona3d

\section{PENDAHULUAN}

\subsection{Latar Belakang}

Perkembangan teknologi semakin pesat pada masa kini. Kemajuan ini membuat teknologi informasi menjadi kebutuhan yang tidak bisa dihiraukan lagi. Peranan teknologi menjadi hal utama yang harus dipenuhi. Tuntutan masyarakat yang menginginkan sesuatu yang praktis membuat internet menjadi hal yang harus ada. Dengan adanya internet pertukaran informasi menjadi lebih mudah dan dapat di akses setiap saat dan dapat di lakukan kapan saja. Media online dewasa ini semakin berkembang dengan berbagai macam kemudahan, dimana media online tersebut selalu berkembang setiap waktu dengan berbagai teknologi yang melengkapi seiring keajuannya, teknologi tersebut misalnya teknologi 3D yang menggambarkan suatu bentuk nyata berada di dunia virtual, teknologi tersebut mampu memberikan visualisasi yang memberikan gambaran yang di informasikan.Teknologi 3D digunakan secara luas di bidang virtual reality, visualisasi ilmiah, simulasi pemodelan, game, aplikasi mobile, dan sebagainya. Konsep dengan grafik telah banyak diterapkan pada perangkat lunak modern dan aplikasinya misalnya: AutoCAD, Maya, CorelDraw, VRML, Open Invertor, dan OpenSceneGraph(Wang, 2010).

Media online berbasis VRML pada Kampus Sistem Komputer Universitas Diponegoro adalah media virtual untuk memudahkan mahasiswa dalam melihat suatu objek kampus melalui website. Dikarenakan VRML adalah teknologi untuk membuat model objek 3 dimensi yang bisa di kembangkan kemudian di akses melalui website. Selain itu VRML dapat digunakan sebagai media presentasi visual yang praktis.

Berdasarkan penelitian sebelumnya teknologi VRML digunakan sebagai media pemasaran perumahan dalam studi kasus PT Setia Graha Pradipta yang di tulis oleh Ahmad Nur Cahyadi dan Mursid W. Hananto. Teknologi ini memiliki keunggulan yang memberikan efisiensi waktu, kesempatan, tenaga dan biaya. Apabila tidak menggunakan VRML ini biasanya di promosikan hanya menggunakan brosur, maket atau gambar. Di lain pihak para calon pembeli banyak yang menanyakan keadaan lokasi, serta apakah lokasi sesuai harapan atau belum. Kebanyakan menginginkan melihat lokasi rumah. Dengan VRML tersebut dapat memberikan keterangan kepada konsumen dengan lebih mudah dan cepat.

Pada Tugas akhir ini akan mengembangkan VRML dalam media prototipe web dengan bahasan virtual kampus Sistem Komputer Fakultas Teknik Universitas Diponegoro. Sehingga kebutuhan informasi yang berkaitan dengan visualisasi kampus akan dapat disimulasikan melalui website yang di akses oleh pencari informasi.

1.2. Rumusan Masalah

Berdasarkan latar belakang masalah tersebut dapat dibuat suatu rumusan masalah, yaitu:

1. Bagaimana merancang virtual kampus dengan Menggunakan VRML pada kampus Sistem Komputer Fakultas Teknik Universitas Diponegoro?

2. Bagaimana mengimplementasikan teknologi virtual reality pada jaringan lokal?

1.3. Batasan Masalah

Dalam penulisan tugas akhir ini pembahasan masalah memiliki batasan pada permasalahan berikut: 
1. Sistem yang di rancang mencakup ruang lingkup kampus Sistem Komputer Fakultas Teknik Universitas Diponegoro.

2. Teknologi yang digunakan merupakan teknologi berbasis web dengan plug-in cortona3d pada browser.

3. Virtualisasi objek meliputi ruang kantor Dosen, ruang Tata Usaha Administrasi, dan ruang kuliah jurusan sistem computer.

4. Pengujian dilakukan pada browser Mozilla Firefox, Google Chrome, dan Internet explorer

1.4. Tujuan Tugas Akhir

1. Membangun sistem denah lokasi dalam bentuk bangunan secara virtual kampus Sistem Komputer Universitas Diponegoro dengan VRML.

2. Mengembangkan sistem media virtual dengan bangunan kampus Sistem Komputer Universitas Diponegoro sebagai objek penelitian dengan VRML.

3. Menguji kinerja aplikasi sehingga dapat berjalan sesuai harapan yang ingin dicapai.

\section{DASAR TEORI}

2.1 Virtual Reality Modelling Language (VRML)

VRML adalah kependekan dari Virtual Reality

Modelling Language. Sebuah bahasa yang di gunakan untuk menggambarkan scene 3D dalam ruangan virtual. Saat ini banyak aplikasi yang mengintegrasikan dukungan format VRML. VRML (Virtual Reality Modelling Language) adalah sebuah bahasa pemrograman yang diciptakan khusus untuk membuat objek-objek 3D. Objek-objek yang dibuat dengan VRML akan memiliki tiga buah dimensi panjang, lebar dan kedalaman, sehingga dapat dipandang dari setiap sudut (Kurniadi 1999). Bahasa ini memberikan berbagai kemudahan bagi pengguna untuk melakukan visualisasi objek-objek 3D (Anwar 1999).

VRML merupakan bahasa yang dapat dimengerti manusia, Sehingga dapat menggunakan editor teks untuk membangun file ini. Terdapat editor khusus yang digunakan untuk mengedit file VRML, yaitu VrmlPad dan aplikasi 3D seperti 3Dsmax. Untuk membuat suatu file VRML di haruskan mengerti sistem koordinat. Sumbu x mempunya arah positif ke kanan, sedang arah positif sumbu y adalah ke atas, Sumbu x dan y ini membelah window browser menjadi dua bagian yang simetri, kiri dengan kanan dan atas dengan bawah. Titik origin dari kedua sumbu tersebut berada tepat di pusat browser. Sedang sumbu z mempunyai arah positif dari monitor ke arah mata kita.

Dunia VRML terbangun dari struktur yang terhierarki. File VRML sendiri adalah hirarki yang paling atas, yang terdiri dari header, scene-graph, prototipe dan event routing. Struktur yang paling bawah adalah node, yang terdiri dari field yang berisi properti dan informasi tentang node yang memilikinya. Node ini akan membangun scene-graph. Keterangan di atas hanya untuk mempermudah imajinasi dan menggambarkan hierarki dari file VRML. Bisa dilihat pada contoh sederhana berikut.

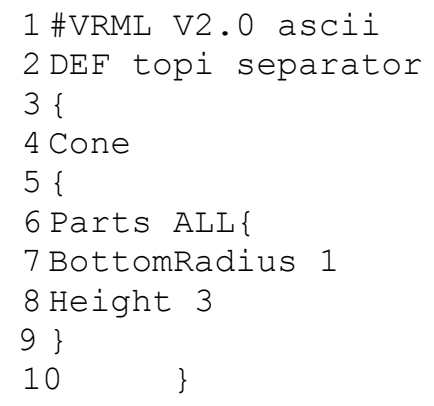

Penjelasan dari listing di atas adalah sebagai berikut:

1. Baris pertama \#VRML V2.0 ascii merupakan header. Di awal setiap program VRML, Header ini yang akan di baca oleh browser untuk mengenali bahwa file tersebut merupakan file 3D VRML. Header harus di ketikkan dengan benar, baik kapitalisasi maupun spasinya.

2. Baris ke dua terdapat objek yang membentuk hingga sifat-sifat yang membentuk objek disebut dengan node. Node juga bisa di ibaratkan sebagai perintah-perintah yang berada di bahasa pemrograman VRML. Node pada VRML terdiri dari tiga macam yaitu: Bentuk, properti,grup.

Setiap node terdiri dari bagian-bagian yang lebih kecil lagi yaitu :

a. Tipe node

Ini adalah jenis node yang digunakan. Tipe ini berupa perintah-perintah dasar VRML dan tidak dapat di ubah-ubah. Sebagai contoh, Cone, Cube, atau Sphere adalah contoh-contoh tipe dari node.

b. Nama node

Nama node digunakan untuk memudahkan, digunakan perintah DEF. misalkan ingin memberi nama node Cube dengan ukuran 10x10x10 dengan nama kubus, ketikkan sebagai berikut:

DEF Kubus

Cube

$$
\begin{aligned}
& \{\text { width } 10 \\
& \text { height } 10 \\
& \text { depth } 10 \text { \} }
\end{aligned}
$$

c. Node anak

Node anak adalah node yang terdapat di dalam node lain.

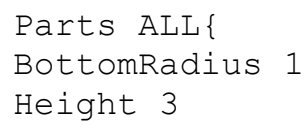

d. Field

Secara keseluruhan dari baris ke 2 hingga baris ke 10 dicakup dalam sebuah field. Field adalah sifat atau property yang dimiliki oleh suatu node.

\subsection{Cortona3D Viewer}

Cortona3d merupakan software yang digunakan sebagai media pelengkap browser dalam mengunduh file vrml yang mengkomunikasikan 3D, dan mudah dipahami. Pengkonfigurasian komponen cukup mudah dan cepat, cortona3d menjadi plug-in yang menjadi salah satu software yang digunakan dalam penyusunan tugas akhir ini. 
Cortona3d viewer yang bekerja sebagai VRML plug-in pada browser seperti: Internet Explorer, Mozilla Firefox, Google Chrome, Opera dan lain-lain, selain itu juga Cortona3d viewer sudah bisa digunakan pada windows platform. Fitur yang ada pada Cortona3d yaitu: support pada VRML 97, support modern 3D acceleration menggunakan DirectX dan OpenGL, rendering (Mipmapping, reflection mapping, dan enhached antialiasing, dapat menggunakan node dan kemampuan tambahan dari spesifikasi VRML, Support untuk adobe flash, user interface yang customizable.

Fitur utama dari Cortona3D Viewer :

1. Sepenuhnya mendukung VRML 97

2. Mendukung $3 D$ accelerator modern via DirectX dan OpenGL

3. Advanced rendering seperti mipmapping, phong lighting, reflection mapping dan endanced anti-aliasing

4. Tambahan node dan kemampuan untuk memperluas spesifikasi VRML

5. Dukungan untuk Adobe Flash

6. Powerfull API berbasis pada teknologi ActiveX Automation

7. Customizable user interface

Kebutuhan sistem untuk plug-in Cortona3D :

1. Sistem Operasi : Windows XP 32-bit Service Pack 3 dan Windows 7 32-bit atau 64-bit

2. Web browser : Internet Explorer 8.0 atau versi yang lebih baru; Mozilla Firefox 4.0 atau versi yang lebih baru; Google Chrome 10 atau versi yang lebih baru; Opera 11 atau versi yang lebih baru; Safari 5 atau versi yang lebih baru

Platform : Processor $1 \mathrm{GHz}$ atau lebih cepat; RAM 1GB; DirectX 9.0c graphics device; tersedia ruang hard disk 20 MB (http://www.cortona3d.com/cortona3dviewer)

\subsection{Bahasa Pemrograman Web}

Saat ini bahasa pemrograman web banyak sekali, setiap orang yang akan membuat pemrograman web tersebut memiliki beberapa pilihan yang di anggap lebih mudah baginya diantara nya adalah : PHP, CSS, dan lain sebagainya.

\subsubsection{HTML}

HTML merupakan kependekan dari Hyper Text Markup Language. HTML adalah file teks murni yang dapat di buat dengan editor teks sembarang. Dokumen ini dikenal sebagai web page. Dokumen HTML merupakan dokumen yang disajikan dalam browser web surfer. Dokumen ini umumnya berisi informasi atau interface aplikasi di dalam internet.

\subsubsection{PHP}

PHP adalah salah satu bahasa pemrograman skrip yang dirancang untuk membangun aplikasi web. Ketika dipanggil dari web browser, program yang ditulis dengan PHP akan di-parsing didalam web server oleh interpreter PHP dan diterjemahkan ke dalam dokumen HTML, yang selanjutnya akan ditampilkan kembali ke web browser. Karena pemrosesan program PHP dilakukan di lingkungan web server, PHP dikatakan sebagai bahasa sisi server (server-side). Oleh sebab itu, kode PHP tidak akan terlihat pada saat user memilih perintah "View Source" pada web browser yang mereka gunakan.

\subsubsection{CSS}

CSS yang merupakan singkatan dari Cascading Style Sheets, merupakan bahasa pemrograman yang digunakan untuk menggambarkan semantik presentasi (tampilan dan format) dari dokumen yang dituliskan dengan menggunakan markup language. Atau dengan kata lain, CSS digunakan untuk memberikan gaya tampilan pada sebuah halaman web yang dituliskan dengan menggunakan bahasa HTML atau XHTML, tetapi bahasa ini juga bisa diaplikasikan pada setiap jenis dokumen XML.

CSS didesain untuk memisahkan konten dokumen dengan presentasi dokumen, termasuk elemen seperti layout, warna, dan pilihan huruf (font). Pemisahan ini akan memberikan keuntungan dalam hal aksesibilitas konten, meningkatkan fleksibilitas, dan memungkinkan beberapa halaman untuk berbagi format yang sama serta mampu mengurangi kompleksitas dan pengulangan dalam penulisan atau struktur konten. Namun dibalik keuntungan - keuntungan penggunaan CSS di atas, ada juga kerugiannya. Karena kode CSS belum tentu bisa diartikan oleh semua browser, sehingga kadang-kadang tampilan tampilan web terlihat berbeda pada browser yang lain bahkan tampilan web rusak atau berantakan.

\subsubsection{MySQL}

MySQL adalah sebuah perangkat lunak sistem manajemen basis data SQL (bahasa Inggris: database management system) atau DBMS yang multithread, multiuser, dengan sekitar 6 juta instalasi di seluruh dunia. Implementasi database bahwa database tersebut dirancang menggunakan perintah-perintah yang dikategorikan sebagai DDL (Data Definition Language). DDL berfungsi melakukan hal-hal sebagai berikut:

1. Membuat atau menghapus basis data

2. Membuat atau menghapus tabel

3. Memodifikasi table

4. Membuat atau menghapus view

5. Menciptakan integritas referensial

6. Membuat index

Selain menggunakan perintah SQL, implementasi database dapat dilakukan menggunakan suatu tool yang dirancang untuk memudahkan proses tersebut. Didalam salah satu database MySQL, tool seperti phpmyadmin yang berbasis web juga cukup membantu dalam mengimplementasikan database tanpa harus menggunakan SQL.

\subsubsection{JavaScript}

Javascript adalah bahasa yang berbentuk kumpulan skrip yang pada fungsinya berjalan pada suatu dokumen HTML, sepanjang sejarah internet bahasa ini adalah bahasa skrip pertama untuk web. Bahasa ini adalah bahasa pemrograman untuk memberikan kemampuan tambahan terhadap bahasa HTML dengan 
mengijinkan pengeksekusian perintah perintah di sisi user, yang artinya di sisi browser bukan di sisi server web (Wahyono 2009).

\subsubsection{JQuery \\ JQuery merupakan sebuah Javascripts Library} atau bisa disebut juga sebagai perpustakaan dari kumpulan kode/listing Javascript yang siap pakai. Dalam arti sederhana, JQuery dapat digunakan untuk meringkas sebuah listing Javascript yang panjang dalam sebuah proyek pembuatan website. Sehingga sebagai web developer, akan diberikan kremudahan dalam menghadapi bagian yang mengandung Javascript. JQuery merupakan program yang berjalan pada sisi server dan akan ditampilkan pada web browser. JQuery dapat berjalan di dalam HTML, atau pemrograman berbasis web lainnya seperti PHP atau JSP (Adi \& Sanjaya 2012).

$2.1 \quad$ Virtual Reality

Virtual Reality didefinisikan sebagai simulasi objek 3D (tiga-dimensi) dengan menggunakan komputer yang dapat dinavigasikan atau dikontrol secara interaktif oleh user (pengguna) di dalam lingkungan dunia maya. Dunia maya tiga dimensi atau virtual reality (VR) merupakan teknologi visualisasi untuk menirukan alam nyata ke dalam dunia maya (Anwar Bachtiar 1999).

\section{$2.2 \quad 3 d s$ Max}

3ds Max adalah program komputer berbasis 3D untuk modeling, rendering, dan animasi yang sangat populer dan banyak di gunakan di berbagai bidang. Dengan variasi objek, material dan pencahayaan yang dimilikinya, 3ds Max biasa digunakan dalam aplikasi arsitektur, interior, mekanik, ataupun industri film dan game. Fitur-fitur yang di sediakan di dalamnya memungkinkan kita menuangkan semua ide kreatif kedalam komputer. Bekerja dengan 3ds Max berarti kita harus memiliki kerangka berpikir 3 dimensi. Kreativitas dan imajinasi terhadap benda-benda 3D dan ruang 3D sangat diperlukan untuk mendukung karya yang baik. Pada umumnya, presisi dalam 3ds Max tidaklah menjadi prioritas sebagaimana pada program-program CAD.

\subsection{Diagram Alur Data / Data Flow Diagram} (DFD)

Ide dari suatu bagan untuk mewakili arus data dalam suatu sistem bukanlah hal yang baru. Pada tahun 1967, Martin dan Estrin memperkenalkan suatu algorima program dengan menggunakan simbol lingkaran dan panah untuk mewakili arus data. E. Yourdan dan L. L. Constantine juga menggunakan notasi simbol ini untuk menggambarkan arus data dalam perancangan program. G.E. Whitehouse tahun 1973 juga menggunakan notasi semacam ini untuk membuat model-model system matematika. Penggunaan notasi dalam diagram arus data ini sangat membantu sekali untuk memahami suatu sistem pada semua tingkat kompleksitasnya seperti yang diungkapkan oleh Chris Gane dan Trish Sarson. Pada tahap analisis, penggunaan notasi ini sangat membantu sekali di dalam komunikasi dengan pemakai sistem untuk memahami sistem secara logika. Diagram yang menggunakan notasi-notasi ini untuk menggambarkan arus dari data sistem sekarang dikenal dengan nama diagram arus data (data flow diagram, DFD).

\section{PERANCANGAN SISTEM}

\subsection{Analisis Kebutuhan}

Seringkali terjadi kesalahan maupun ketidaksepahaman antara aplikasi yang dibuat dengan keinginan dari pengguna aplikasi. Hal ini biasa terjadi karena dalam pembuatannya tidak diawali dengan analisis kebutuhan yang mendasar dan rinci.

Permasalahan merupakan latar belakang untuk membangun sebuah sistem yang baru, seringkali perekayasa perangkat lunak kesulitan dalam menentukan apa saja yang harus dilakukan oleh sistem. Deskripsi layanan dan batasan merupakan kebutuhan bagi sistem dan proses menemukan, menganalisis, mendokumentasikan dan memeriksa layanan dan batasan ini disebut analisis kebutuhan. Analisis kebutuhan ini diperlukan agar sistem dapat mencapai tujuan yang diharapkan.

\subsection{Analisis Sistem}

Analisis sistem merupakan kegiatan untuk melihat sistem yang nantinya akan ditangani oleh perangkat lunak. Analisis sistem ini diperlukan untuk memahami domain informasi dan tingkah laku sistem yang diperlukan mengacu pada tahap analisa kebutuhan yang telah dilakukan sebelumnya. Perancangan Portal Kegiatan Perkuliahan ini menggunakan metode pemodelan permrograman terstruktur yaitu DFD (Data Flow Diagram) untuk menggambarkan aliran informasi dan transformasi informasi yang diaplikasikan sebagai data yang mengalir dari masukkan (input) dan keluaran (output).

\subsubsection{Data Flow Diagram}

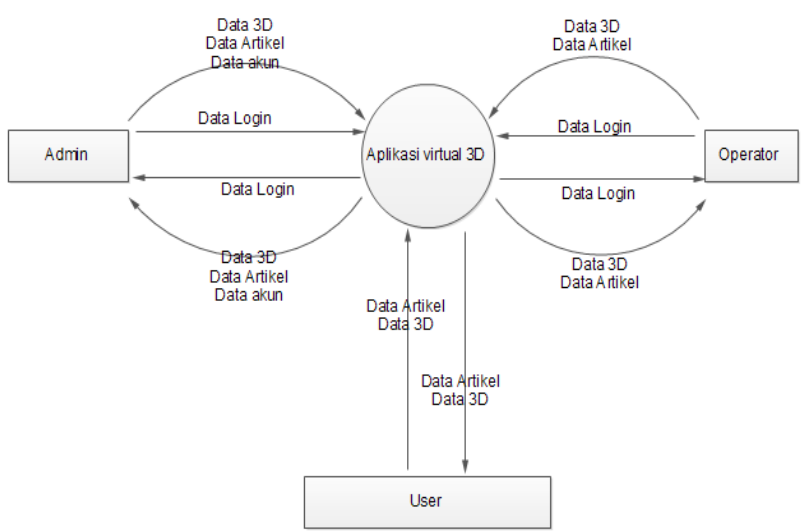

Gambar 1. Data flow diagram level 0

Pada DFD level 0 menjelaskan tentang proses di sistem aplikasi virtual 3D berbasis jaringan lokal terdiri dari dua entitas 


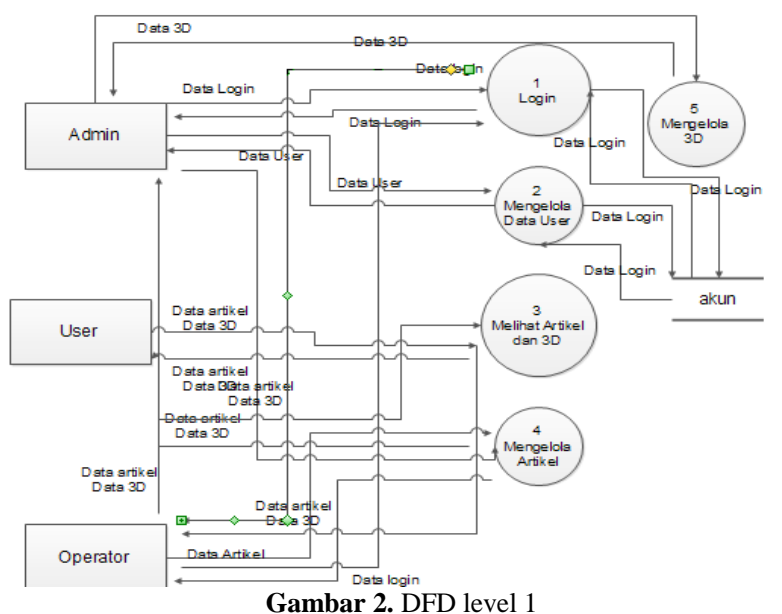

Gambar 2. DFD level 1

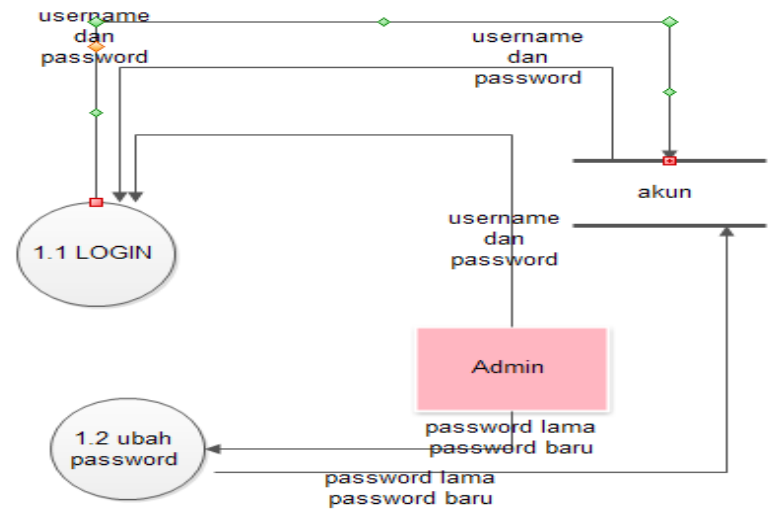

Gambar 3. DFD level 2 proses 1

DFD level 2 proses 2 merupakan proses dari pengelolaan akun yang dapat dilakukan oleh admin. Admin dapat melakukan proses tambah, ubah dan hapus data akun. Hasil dari pengelolaan akan disimpan pada data store.

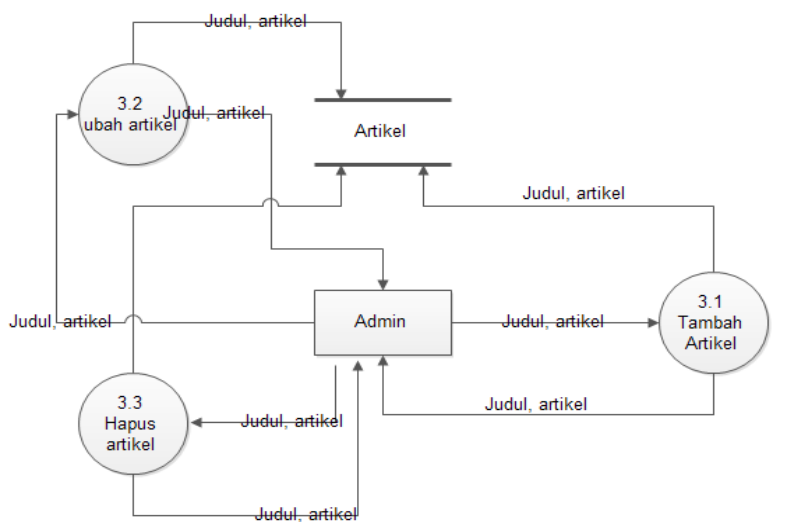

Gambar 4. DFD level 2 proses 3

DFD level 2 proses 3 merupakan proses dari pengelolaan artikel yang dapat dilakukan oleh admin. Admin dapat melakukan proses tambah, ubah dan hapus artikel. Hasil dari pengelolaan akan disimpan pada data store tambah_artikel.

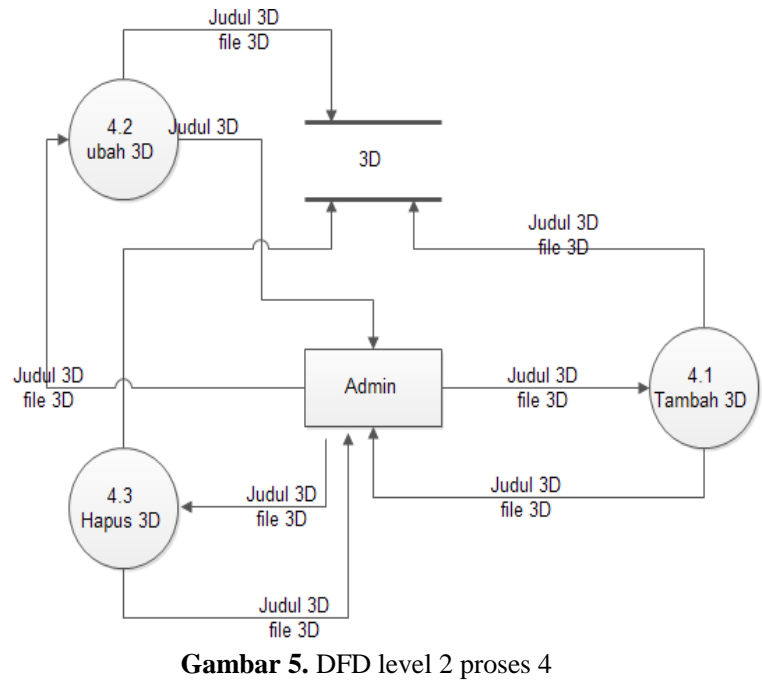

DFD level 2 proses 4 merupakan proses dari pengelolaan file 3D yang dapat dilakukan oleh admin. Admin dapat melakukan proses tambah, ubah dan hapus file 3D. Hasil dari pengelolaan akan disimpan pada data store tambah_3D.

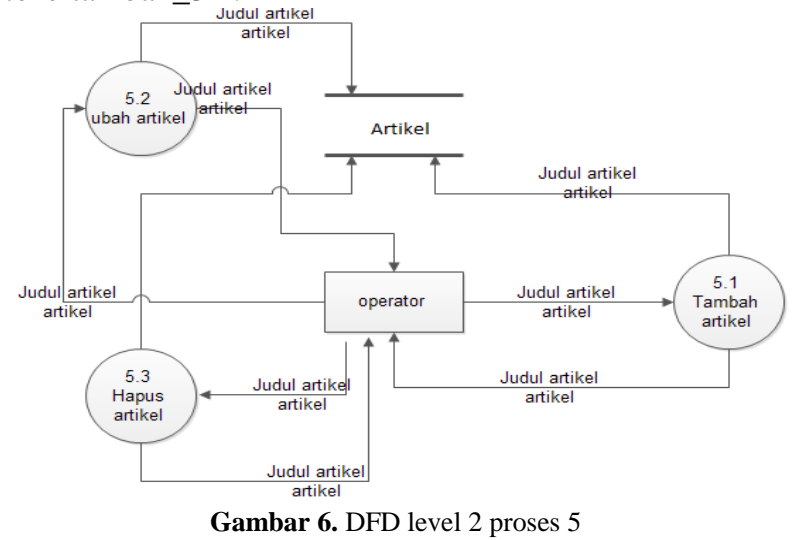

DFD level 2 proses 5 merupakan proses dari pengelolaan artikel yang dapat dilakukan oleh operator. Admin dapat melakukan proses tambah, ubah dan hapus artikel. Hasil dari pengelolaan akan disimpan pada data store tambah_artikel.

\subsection{Perancangan Basis Data}

MySQL merupakan basis data yang digunakan dalam membangun aplikasi pemesanan makanan berbasis mobile ini. Pada tabel basis data terdapat kunci PK (Primary Key) dan kunci FK (Foreign Key) yang menunjukkan adanya relasi/hubungan antar tabel dalam basis data. Dimana relasi/hubungan antar tabel tersebut berfungsi untuk mengatur operasi suatu basis data.

\section{IMPLEMENTASI DAN PENGUJIAN SISTEM}

\subsection{Implementasi Program}

Langkah pertama kali dalam pembuatan apliksi ini membuat dan mengimport 3d ke file ekstensi .wrl kemudian menguji pada browser apakah dapat berjalan dengan baik atau tidak.

1. Implementasi VRML pada browser

Pada tahap ini, pembuatan 3d kampus pada aplikasi 3dsmax yang kemudian dilanjutkan dimulai dengan membuka file dengan ekstensi .wrl yang telah di buat pada browser yang sudah terpasang plug in 
cortona3D. maka akan muncul tampilan seperti gambar

berikut.

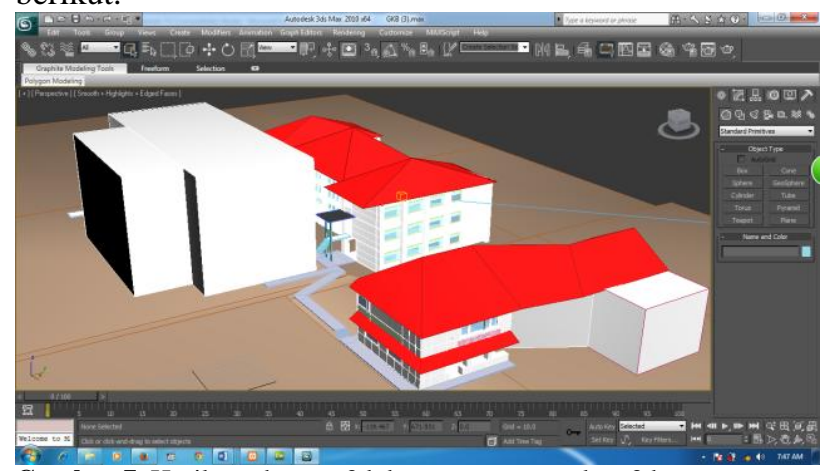

Gambar 7. Hasil pembuatan 3d dengan menggunakan 3dsmax

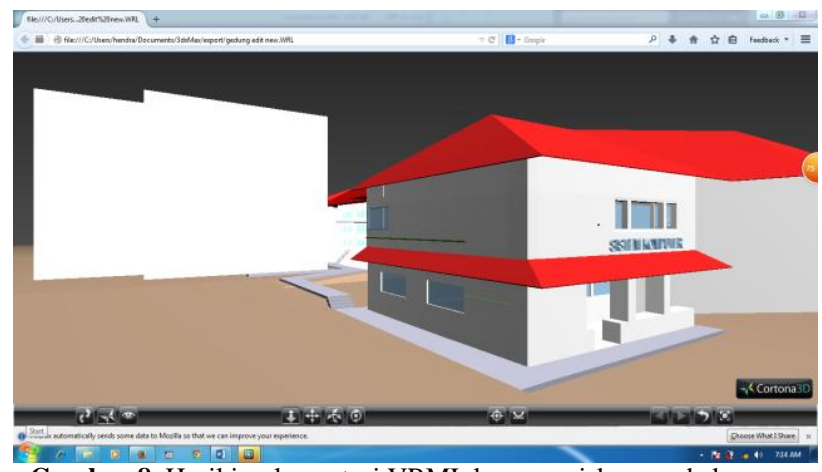

Gambar 8. Hasil implementasi VRML kampus siskom pada browser

2. Implementasi VRML pada web

Langkah awal dalam membuat tampilan 3 dimensi pada web yaitu menyediakan basis data untuk menyimpan file dengan ekstensi .wrl dan memanggilnya pada halaman yang telah di tentukan.

Langkah pertama membuat 3 dimensi menggunakan aplikasi 3dsmax, kemudian hasil dari pembuatan di export menjadi ekstensi file .wrl.

Langkah kedua yaitu admin membuka halaman objek $3 d$ list. Kemudian mengunggah file dengan ekstensi .wrl tersebut dengan memberikan nama. Kemudian menentukan file mana yang akan di tampilkan.

Langkah selanjutnya yaitu mengatur ulang script apabila tampilan belum sesuai dengan panjang dan lebar web.

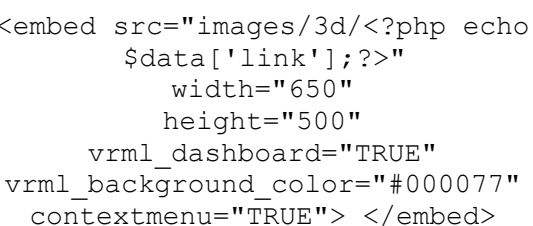

Melihat Virtual Campus
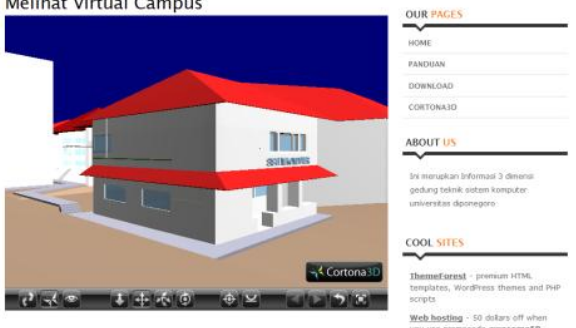

Gambar 9. Hasil penyesuaian tampilan 3d pada halaman web
Setelah mengubah tampilan objek sesuai yang di inginkan maka langkah selanjutnya adalah membuat basis data.

Pembuatan basis data

Dalam pembuatan basis data maka harus di tentukan apa saja yang akan di simpan dalam basis data tersebut.

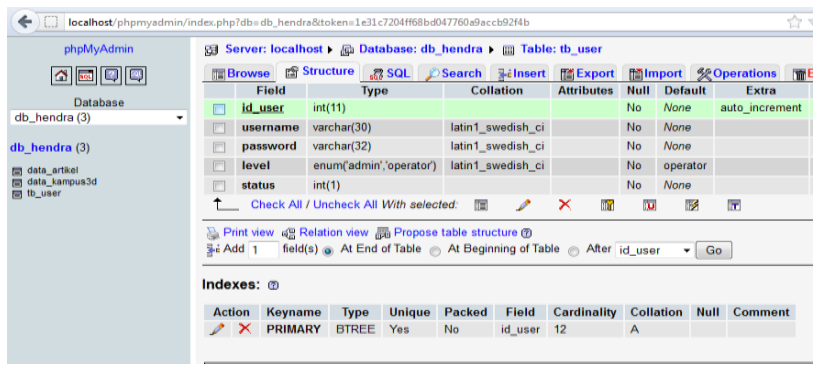

Gambar 10. Hasil tampilan struktur tb_user

Pada gambar di atas terdapat tabel data_artikel, data_kampus3d, dan tb_user. Dimana masing-masing tabel menyimpan data yang di hubungkan dengan web.

Pembuatan web

Setelah semua langkah - langkah di atas selesai dilakukan, maka membuat desain web pada halamanhalaman yang lain seperti home, panduan, download, cortona3d, admin, dan login.

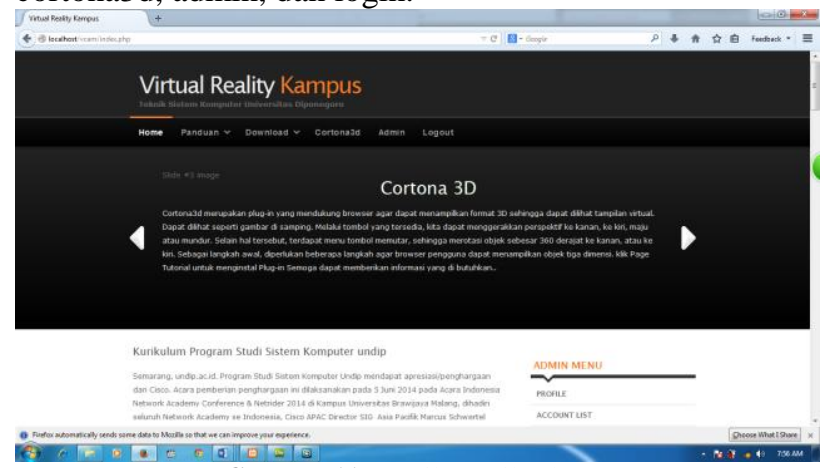

Gambar 11. .Hasil tampilan home

Desain halaman pengunduhan aplikasi terdapat link yang menghubungkan pada web cortona untuk memudahkan user umum. Apabila belum mengunduh software cortona3d maka dapat mengunduh pada halaman Download

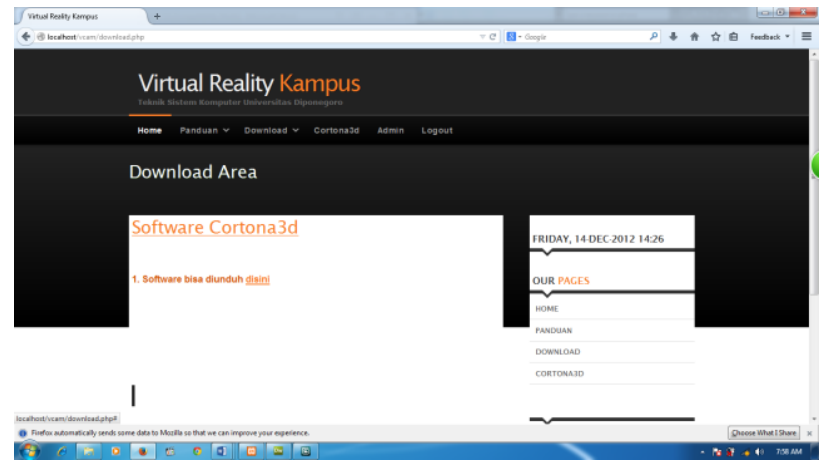

Gambar 12.Hasil tampilan halaman download

Pemberian hak akses pada user merupakan hal yang penting. Setiap user adalah aktor, dimana dalam aplikasi ini terdapat tiga aktor yaitu admin, operator, dan user luar atau pengguna umum. Admin adalah aktor yang dapat mengubah passwordnya sendiri, dapat mengganti password operator, admin dapat memilih opsi $3 \mathrm{~d}$ yang di 
tampilkan serta menghapusnya. Hak untuk mengunggah artikel, mengedit dan menghapus.

Hak untuk operator hanya dapat mengunggah dan mengedit dan menghapus artikel. Untuk mengubah password dapat dilakukan dengan menghubungi admin untuk perubahan.

User yang memasuki web akan ditujukan pada halaman home yang berisikan artikel. Kemudian dapat memasuki halaman lain kecuali melakukan login karena tidak mempunyai akun.

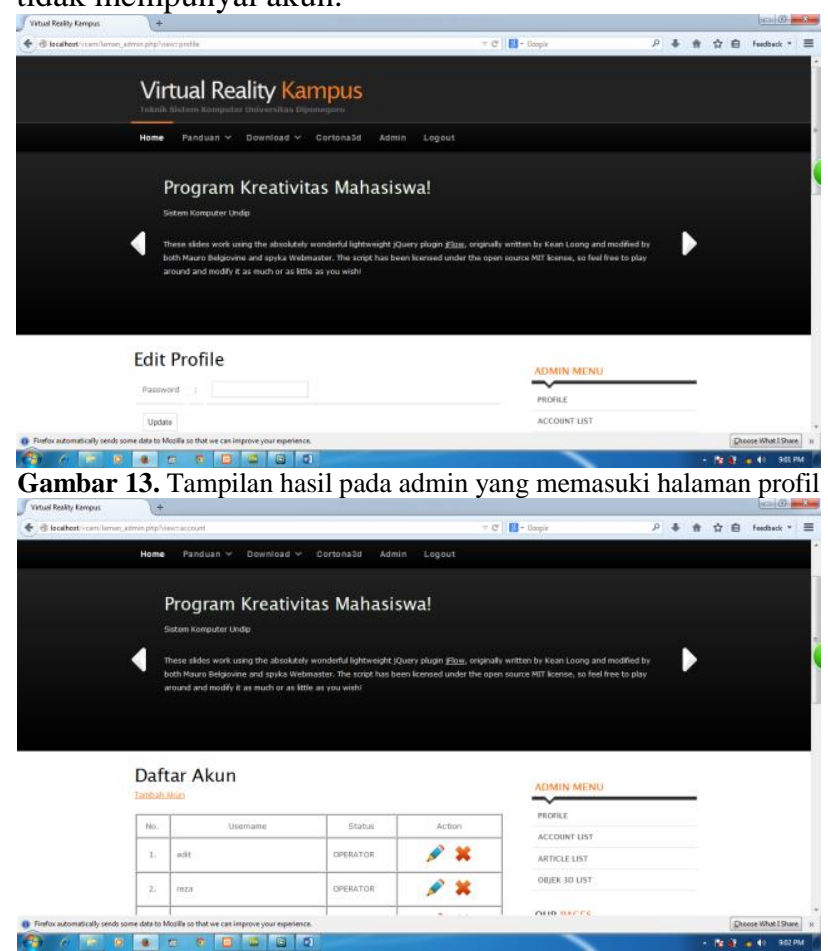

Gambar 14. Tampilan hasil pada admin yang memasuki halaman account list

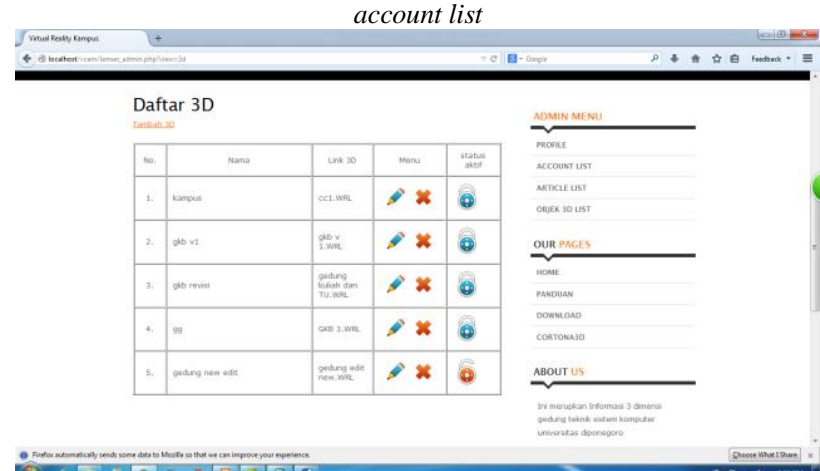

Gambar 15. Tampilan hasil pada admin yang memasuki halaman $3 d$ list

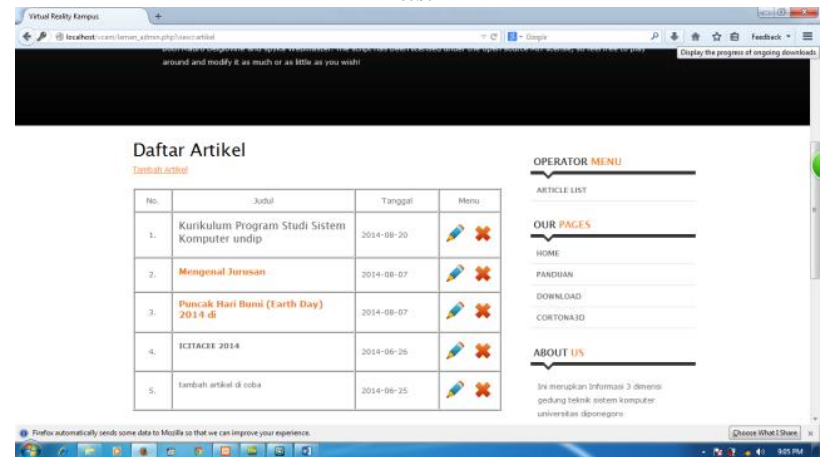

Gambar 16. Tampilan hasil pada operator yang memasuki halaman article list

\subsection{Pengujian}

Pengujian aplikasi bertujuan untuk memastikan bahwa aplikasi telah memiliki fungsi seperti yang diharapkan dan mencari kesalahan yang terdapat pada aplikasi Virtual reality.

Pengujian aplikasi ini terdiri dari proses Pengujian instalasi aplikasi, dan pengujian semua basis data. Hasil pengujian dapat dilihat pada tabel 1 Pengujian aplikasi :

Tabel 1. Uji coba aplikasi

\begin{tabular}{|c|c|c|c|}
\hline $\begin{array}{c}\text { Nama } \\
\text { Pengujian }\end{array}$ & $\begin{array}{c}\text { Bentuk } \\
\text { Pengujian }\end{array}$ & $\begin{array}{c}\text { Hasil Yang } \\
\text { Diharapkan }\end{array}$ & $\begin{array}{c}\text { Hasil } \\
\text { Pengujian }\end{array}$ \\
\hline \multirow[t]{4}{*}{$\begin{array}{l}\text { Pengujian } \\
\text { menu } \\
\text { login }\end{array}$} & $\begin{array}{l}\text { 1. Memasukkan } \\
\text { username dan } \\
\text { password } \\
\text { benar }\end{array}$ & $\begin{array}{l}\text { 1. Muncul } \\
\text { halaman } \\
\text { utama sesuai } \\
\text { dengan level } \\
\text { pengguna }\end{array}$ & Berhasil \\
\hline & $\begin{array}{l}\text { 2. Memasukkan } \\
\text { username } \\
\text { salah dan } \\
\text { password } \\
\text { benar }\end{array}$ & $\begin{array}{l}\text { 2. Muncul pesan } \\
\text { untuk } \\
\text { mengisi } \\
\text { username dan } \\
\text { password }\end{array}$ & Berhasil \\
\hline & $\begin{array}{l}\text { 3. Memasukkan } \\
\text { username } \\
\text { benar dan } \\
\text { password } \\
\text { salah } \\
\end{array}$ & $\begin{array}{l}\text { 3. Muncul pesan } \\
\text { untuk } \\
\text { mengisi } \\
\text { username dan } \\
\text { password }\end{array}$ & Berhasil \\
\hline & $\begin{array}{ll}\text { 4. } & \text { Tidak } \\
\text { memasukkan } \\
\text { username dan } \\
\text { password }\end{array}$ & $\begin{array}{l}\text { 4. Muncul pesan } \\
\text { untuk } \\
\text { mengisi } \\
\text { username dan } \\
\text { password } \\
\end{array}$ & Berhasil \\
\hline $\begin{array}{l}\text { Pengujian } \\
\text { menu } \\
\text { logout }\end{array}$ & Klik menu logout & $\begin{array}{c}\text { Menuju ke } \\
\text { halaman awal } \\
\text { dan tulisan } \\
\text { logout berganti } \\
\text { login }\end{array}$ & Berhasil \\
\hline \multirow[t]{2}{*}{$\begin{array}{l}\text { Pengujian } \\
\text { ubah } \\
\text { password }\end{array}$} & $\begin{array}{l}\text { 1. Klik menu } \\
\text { ubah } \\
\text { password }\end{array}$ & $\begin{array}{l}\text { 1. Muncul } \\
\text { halaman untuk } \\
\text { mengubah } \\
\text { password } \\
\text { sesuai } \\
\text { username } \\
\text { pengguna }\end{array}$ & Berhasil \\
\hline & $\begin{array}{ll}\text { 2. } & \text { Memasukkan } \\
\text { password } \\
\text { baru }\end{array}$ & $\begin{array}{l}\text { 2. Muncul } \\
\text { halaman pesan } \\
\text { "Update } \\
\text { berhasil" }\end{array}$ & Berhasil \\
\hline
\end{tabular}

Tabel 2 pengujian aplikasi

\begin{tabular}{|c|c|c|c|}
\hline $\begin{array}{c}\text { Nama } \\
\text { Pengujia } \\
\text { n }\end{array}$ & $\begin{array}{c}\text { Bentuk } \\
\text { Pengujian }\end{array}$ & $\begin{array}{c}\text { Hasil Yang } \\
\text { Diharapkan }\end{array}$ & $\begin{array}{c}\text { Hasil } \\
\text { Pengujian }\end{array}$ \\
\hline $\begin{array}{c}\text { Pengujian } \\
\text { menu } \text { user }\end{array}$ & $\begin{array}{c}\text { Klik menu } \\
\text { account list }\end{array}$ & $\begin{array}{c}\text { Muncul daftar } \\
\text { user }\end{array}$ & Berhasil \\
\hline $\begin{array}{c}\text { Pengujian } \\
\text { tambah } \\
\text { user }\end{array}$ & $\begin{array}{l}\text { Klik menu } \\
\text { tambah } \text { user }\end{array}$ & $\begin{array}{l}\text { Muncul } \\
\text { tampilan untuk } \\
\text { menambah } \\
\text { user baru }\end{array}$ & Berhasil \\
\cline { 2 - 5 } & $\begin{array}{l}\text { Mengisi hak } \\
\text { akses }\end{array}$ & $\begin{array}{l}\text { Muncul data } \\
\text { yang telah } \\
\text { dimasukan } \\
\text { pada pilihan } \\
\text { user }\end{array}$ & Berhasil \\
\cline { 2 - 5 } & $\begin{array}{l}\text { Salah satu } \\
\text { dari form } \\
\text { tambah } \text { user } \\
\text { tidak diisi }\end{array}$ & $\begin{array}{l}\text { Muncul pesan } \\
\text { untuk mengisi } \\
\text { username dan } \\
\text { password }\end{array}$ & Berhasil \\
\hline $\begin{array}{c}\text { Pengujian } \\
\text { edit } \text { user }\end{array}$ & $\begin{array}{l}\text { Klik gambar } \\
\text { edit } \text { user }\end{array}$ & $\begin{array}{l}\text { 1. } \\
\text { Muncul } \\
\text { tampilan untuk }\end{array}$ & Berhasil \\
\hline
\end{tabular}




\begin{tabular}{|c|c|c|c|}
\hline & & $\begin{array}{l}\text { mengedit } \text { user } \\
\text { sesuai } \\
\text { username yang } \\
\text { dipilih }\end{array}$ & \\
\cline { 2 - 4 } & $2 . \quad \begin{array}{c}\text { Mengedit } \\
\text { status atau } \\
\text { password }\end{array}$ & $\begin{array}{c}\text { Muncul data } \\
\text { yang telah } \\
\text { diubah pada } \\
\text { daftar } \text { user }\end{array}$ & Berhasil \\
\hline $\begin{array}{c}\text { Pengujian } \\
\text { hapus } \\
\text { user }\end{array}$ & $\begin{array}{c}\text { Klik gambar } \\
\text { hapus } \text { user }\end{array}$ & $\begin{array}{c}\text { Muncul tampilan } \\
\text { peringatan apakah } \\
\text { ingin menghapus } \\
\text { data ini }\end{array}$ & Berhasil \\
\hline
\end{tabular}

Tabel 3 Pengujian Aplikasi

\begin{tabular}{|c|c|c|c|}
\hline $\begin{array}{c}\text { Nama } \\
\text { Pengujian }\end{array}$ & $\begin{array}{c}\text { Bentuk } \\
\text { Pengujian }\end{array}$ & $\begin{array}{c}\text { Hasil Yang } \\
\text { Diharapkan }\end{array}$ & $\begin{array}{c}\text { Hasil } \\
\text { Pengujian }\end{array}$ \\
\hline $\begin{array}{l}\text { Pengujian } \\
\text { menu daftar } \\
\text { artikel }\end{array}$ & $\begin{array}{l}\text { Klik menu } \\
\text { artikel list }\end{array}$ & $\begin{array}{l}\text { Muncul daftar } \\
\text { artikel }\end{array}$ & Berhasil \\
\hline \multirow{3}{*}{$\begin{array}{l}\text { Pengujian } \\
\text { tambah } \\
\text { artikel }\end{array}$} & $\begin{array}{l}\text { 1. Klik menu } \\
\text { tambah } \\
\text { artikel }\end{array}$ & $\begin{array}{ll}\text { 1. } & \text { Muncul } \\
\text { tampilan } \\
\text { untuk } \\
\text { menambah } \\
\text { Artikel baru }\end{array}$ & Berhasil \\
\hline & 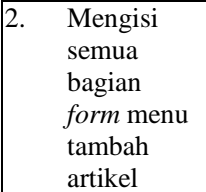 & $\begin{array}{ll}\text { 2. } & \text { Muncul data } \\
\text { yang telah } \\
\text { ditambahkan } \\
\text { pada daftar } \\
\text { artikel }\end{array}$ & Berhasil \\
\hline & \begin{tabular}{|l} 
3. \\
Salah satu \\
dari form \\
tambah \\
artikel \\
tidak diisi
\end{tabular} & 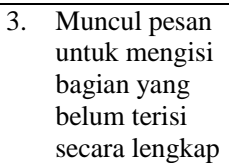 & Berhasil \\
\hline \multirow[b]{2}{*}{$\begin{array}{l}\text { Pengujian } \\
\text { edit artikel }\end{array}$} & $\begin{array}{ll}\text { 1. } & \text { Klik } \\
\text { gambar edit } \\
\text { artikel }\end{array}$ & $\begin{array}{ll}\text { 1. } & \text { Muncul } \\
& \text { tampilan } \\
& \text { untuk } \\
& \text { mengedit } \\
& \text { artikel }\end{array}$ & Berhasil \\
\hline & 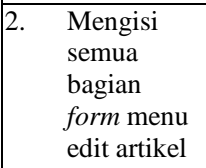 & $\begin{array}{ll}\text { 2. } & \text { Muncul data } \\
& \text { yang telah } \\
& \text { diubah pada } \\
& \text { daftar artikel }\end{array}$ & Berhasil \\
\hline $\begin{array}{c}\text { Pengujian } \\
\text { hapus artikel }\end{array}$ & $\begin{array}{l}\text { Klik gambar } \\
\text { hapus artikel }\end{array}$ & $\begin{array}{l}\text { Muncul tampilan, } \\
\text { pilihan untuk } \\
\text { menghapus }\end{array}$ & Berhasil \\
\hline
\end{tabular}

Tabel 4 Pengujian Aplikasi

\begin{tabular}{|c|c|c|c|}
\hline $\begin{array}{c}\text { Nama } \\
\text { Pengujian }\end{array}$ & $\begin{array}{c}\text { Bentuk } \\
\text { Pengujian }\end{array}$ & $\begin{array}{l}\text { Hasil Yang } \\
\text { Diharapkan }\end{array}$ & $\begin{array}{c}\text { Hasil } \\
\text { Pengujian }\end{array}$ \\
\hline $\begin{array}{l}\text { Pengujian } \\
\text { menu daftar } \\
\text { 3D }\end{array}$ & $\begin{array}{l}\text { Klik menu } \\
\text { objek 3D list }\end{array}$ & Muncul daftar 3D & Berhasil \\
\hline \multirow{3}{*}{$\begin{array}{l}\text { Pengujian } \\
\text { tambah 3D }\end{array}$} & $\begin{array}{ll}\text { 4. } & \text { Klik menu } \\
& \text { tambah 3D }\end{array}$ & $\begin{array}{l}\text { 4. } \begin{array}{l}\text { Muncul } \\
\text { tampilan untuk } \\
\text { menambah 3D } \\
\text { baru }\end{array} \\
\end{array}$ & Berhasil \\
\hline & \begin{tabular}{|ll}
5. & Mengisi \\
& semua \\
& bagian \\
& form menu \\
tambah 3D
\end{tabular} & \begin{tabular}{|ll}
5. & Muncul data \\
& yang telah \\
& ditambahkan \\
& pada daftar 3D
\end{tabular} & Berhasil \\
\hline & $\begin{array}{ll}\text { 6. Salah satu } \\
\text { dari form } \\
\text { tambah 3D } \\
\text { tidak diisi }\end{array}$ & 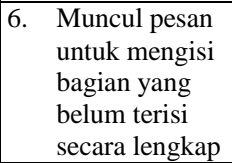 & Berhasil \\
\hline $\begin{array}{l}\text { Pengujian } \\
\text { edit 3D }\end{array}$ & $\begin{array}{ll}\text { 3. } & \text { Klik } \\
& \text { gambar edit }\end{array}$ & 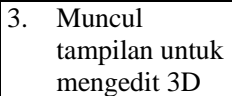 & Berhasil \\
\hline
\end{tabular}

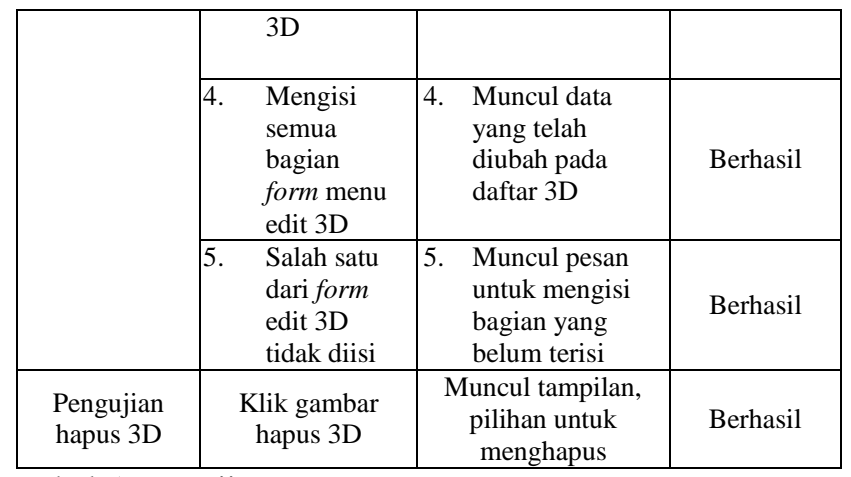

Tabel 5 Pengujian Browser

\begin{tabular}{|c|c|c|c|}
\hline $\begin{array}{c}\text { Nama } \\
\text { Pengujian }\end{array}$ & Google Chrome & $\begin{array}{l}\text { Mozilla } \\
\text { Firefox }\end{array}$ & $\begin{array}{l}\text { Internet } \\
\text { Explorer }\end{array}$ \\
\hline $\begin{array}{l}\text { Pengujian } \\
\text { Web }\end{array}$ & Berhasil & Berhasil & Berhasil \\
\hline $\begin{array}{l}\text { Pengujian } \\
\text { Menu }\end{array}$ & Berhasil & Berhasil & Berhasil \\
\hline $\begin{array}{l}\text { Pengujian } \\
\text { Plug-in } \\
\text { cortona3d }\end{array}$ & Berhasil & Berhasil & Berhasil \\
\hline
\end{tabular}

Tabel 6 pengujian rendering menggunakan aplikasi peacekeeper

\begin{tabular}{|c|c|c|c|}
\hline & $\begin{array}{c}\text { Google } \\
\text { chrome }\end{array}$ & $\begin{array}{c}\text { Mozilla } \\
\text { firefox }\end{array}$ & $\begin{array}{c}\text { Internet } \\
\text { Explorer }\end{array}$ \\
\hline Rendering & $87.7 \mathrm{fps}$ & $43.02 \mathrm{fps}$ & $\begin{array}{c}79.65 \\
\mathrm{fps}\end{array}$ \\
\hline $\begin{array}{c}\text { Rendering } \\
\text { Grid01 }\end{array}$ & $\begin{array}{c}158.24 \\
\mathrm{fps}\end{array}$ & $65.44 \mathrm{fps}$ & $\begin{array}{c}195.81 \\
\mathrm{fps}\end{array}$ \\
\hline $\begin{array}{c}\text { Rendering } \\
\text { Grid02 }\end{array}$ & $\begin{array}{c}137.71 \\
\mathrm{fps}\end{array}$ & $82.59 \mathrm{fps}$ & $\begin{array}{c}174.09 \\
\mathrm{fps}\end{array}$ \\
\hline $\begin{array}{c}\text { Rendering } \\
\text { Grid03 }\end{array}$ & $30.03 \mathrm{fps}$ & $11.10 \mathrm{fps}$ & $\begin{array}{c}11.74 \\
\mathrm{fps}\end{array}$ \\
\hline $\begin{array}{c}\text { Render Physic } \\
\text { html 5 }\end{array}$ & $90.41 \mathrm{fps}$ & $57.07 \mathrm{fps}$ & $\begin{array}{c}100.59 \\
\mathrm{fps}\end{array}$ \\
\hline $\begin{array}{c}\text { capabilities } \\
\text { (webglSphere) }\end{array}$ & $59.76 \mathrm{fps}$ & $60.07 \mathrm{fps}$ & $\mathrm{n} / \mathrm{a}$ \\
\hline $\begin{array}{c}\text { Result } \\
\text { benchmark }\end{array}$ & 4104 & 3067 & 2411 \\
\hline
\end{tabular}

\section{KESIMPULAN}

Berdasarkan hasil pengujian dan analisis aplikasi Virtual Reality Kampus, maka dapat disimpulkan hal-hal sebagai berikut: 
1. Aplikasi Virtual Reality Kampus membangun sistem denah lokasi dalam bentuk bangunan secara virtual kampus Sistem Komputer Universitas Diponegoro dengan VRML.

2. Media virtual dengan bangunan kampus Sistem Komputer Universitas Diponegoro sebagai objek penelitian dengan VRML berhasil di kembangkan.

3. Aplikasi Virtual Reality Kampus dapat berjalan sesuai dengan skenario sistem yang telah dirancang.

4. Pengujian aplikasi Virtual Reality Kampus dengan menggunakan black box berhasil sesuai dengan hasil yang diharapkan.

5. Berdasarkan pengujian, semua menu Aplikasi Virtual Reality Kampus sudah berjalan sesuai dengan fungsinya.

6. Browser Internet Google Chrome merupakan browser dengan rendering terbaik.

\section{SARAN}

Berdasarkan pengujian terhadap aplikasi Virtual

Reality Kampus, yang telah dibuat, dapat diberikan beberapa saran sebagai berikut:

1. Aplikasi Virtual Reality Kampus dapat dikembangkan lebih lanjut agar dapat terhubung dengan Sistem Informasi Akademik yang terdapat di Jurusan Sistem Komputer.

2. Membangun objek 3d lebih baik menggunakan vertex dan polygon seminimal mungkin.

3. Aplikasi Virtual Reality Kampus dapat dikembangkan untuk aplikasi Smartphone.

\section{DAFTAR PUSTAKA}

[1] Adi, A.P. \& Sanjaya, R., 2012. Web Makin Dahsyat dengan JQuery, Semarang: Kompas Gramedia.

[2] Anon, www.it-ebooks.info, Birmingham: Packt Publishing Ltd. Available at: www.it-ebooks.info.

[3] Anwar, B., 1999. Belajar Sendiri Bahasa Permrograman VRML 97, Jakarta: PT Elex Media Komputindo.

[4] Anwar Bachtiar, 1999. Belajar sendiri bahasa pemrograman VRML 1.0, Jakarta : Elex Media Komputindo.

[5] Coltekin, A., Heikkinen, J. \& Ronnholm, P., 2003. Studying Geometry, Color, and Texture in VRML, Helsinki: Institute of Photogrammetry and Remote Sensing, Helsinki University of Technology.

[6] Fadillah, M.H., 2011. Implementasi VRML pada Media Pembelajaran Untuk Sekolah Dasar Dengan Menggunakan Metode Pembentukan Objek Ekstrusi.

[7] Hirin, A.. \& Virgi, 2011. Cepat Mahir Pemrograman Web demgan PHP dan MySQL, Jakarta: Prestasi Pustakarya.

[8] Kadir, A., 2009. Mastering AJAX dan PHP, Yogyakarta: Andi Offset.

[9] Kurniadi, A., 1999. Membuat Dunia 3D dengan VRML, Jakarta: PT Elex Media Komputindo.

[10] Nugroho, Bunafit. 2008. Latihan Membuat Aplikasi Web $P H P$ dan MySQL dengan Dreamweaver, Gaya Media, Yogyakarta,

[11] MADCOMS, 2011. Dreamweaver CS 5 PHP - My SQL untuk Pemula, Madiun: ANDI.

[12] Paoluzzi, A., 2003. Geometric Programming for Computer Aided Design, Chicester, UK: John Wiley \& Sons.

[13]Wahyono, T., 2009. Practice Guide PHP On Windows, Jakarta: PT Elex Media Komputindo.

[14] http://www.cortona3d.com/cortona3d-viewers diakses pada tanggal 26 Oktober 2013 pukul 13.59 